\title{
Sheesha Smoking Habits in Young Pakistani Female Students
}

\author{
Amena T. Rahim, FCPS, Khadija I. Iqbal ${ }^{1}$, FCPS, and \\ Tehmina S. Qamar ${ }^{2}$, FCPS \\ Department of Biochemistry, \\ Rawal Institute of Health Sciences, Bahria University \\ ${ }^{1}$ Department of Anatomy, Al-Nafees Medical College, Islamabad \\ ${ }^{2}$ Department of Biochemistry, Rawalpindi Medical College, \\ Rawalpindi, Pakistan \\ dr_aminatariq@yahoo.com
}

\begin{abstract}
Sheesha smoking habit is found to be most prevalent in the $16-25$ years age group with $70 \%$ sheesha smokers being male and $30 \%$ females. Alarming consequence is that either the customers or the people who serve it put addictive substances into it. The present study aims to assess the growing habits of sheesha smoking in Pakistani female students. Questionnaire was distributed among the girl students. Female students from different colleges/universities of Rawalpindi and Islamabad were included in the study. Statistics show that students offer each other the option to smoke sheesha, i.e., 51.6\%. In this study's setting, $61.1 \%$ started sheesha smoking during their college life, and is considered fashionable by $68.1 \%$ and $54.9 \%$ are not aware of its harmful effects. Not much difference was seen between the parents about the awareness of their children sheesha smoking habit, i.e., $48.9 \%$ and $50.5 \%$. $35.2 \%$ thought of it as losing weight tool and $22 \%$ to relieve depression. A large majority agreed that government should check this habit (78\%). Government should get more actively involved against sheesha bars and to check for the banned substances. Study needs to be expanded to smaller cities.
\end{abstract}

Keywords: Sheesha, Smoking, Pakistani females.

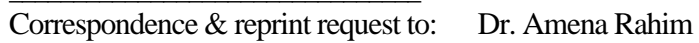

House 178, Lane 7, Askari 13 Adiala Rd. Rawalpindi, Pakistan

Accepted for publication: 30 December 2013. Received: 16 June 2013. 


\section{Introduction}

Smoking is a major cause of premature deaths worldwide. Hazards of smoking has been extensively studied and documented ${ }^{[1]}$. Sheesha smoking also called Hookah is becoming extensive and is considered as an epidemic and a global threat ${ }^{[2]}$.

In developing countries, $48 \%$ of men and $7 \%$ of women smoke, while in developed countries, $42 \%$ of men smoke as compared to $24 \%$ of women ${ }^{[3]}$. Tobacco smoke contains 4800 chemicals, which are both pro-carcinogens and carcinogens and they have been associated with a number of cancers ${ }^{[4]}$. According to the Global Youth Tobacco survey (GYTS) presented by World Health Organization (WHO), $25 \%$ of smokers smoked their first cigarette before the age of 10 , which means that smoking of family members and friends may be having a great impact on the young adults ${ }^{[5]}$. Transition from adolescence to puberty is a critical phase in every person's life and that is the time when he or she is most vulnerable to be influenced by the people around them, and they can take up different habits including smoking. According to the GYTS conducted in 131 countries which surveyed 750,000 students of ages 13-15 years found that approximately $9 \%$ of students were current smokers, while $11 \%$ currently used tobacco products other than cigarettes ${ }^{[6]}$. New generation is under the impression that smoking distracts people from eating and helps curb appetite. The chemicals and tar in cigarettes coat the inside of mouth and cover the taste buds so that they become less effective. This theory has attracted the young generation to use it as a tool for losing weight ${ }^{[7]}$. Sheesha also known as water pipe or Hookah is basically a smoking device in which smoke is cooled and filtered by water. One puff of sheesha smoke contains more than 5000 active chemicals out of which at least more than 100 are carcinogenic. Alarming consequence is that either the customers or the people who serve it put addictive substances into it. The present study aims to assess the growing habit of sheesha smoking in Pakistani female students. 


\section{Material and Methods}

Cross-sectional data was collected after obtaining verbal consent from the students. Ninety (90) female students from first and second semesters were included from different colleges or universities of Rawalpindi and Islamabad. Fresh inductees and those who had spent a year in the university were evaluated. Also, this age group of teenagers is more likely to be influenced by the habits of their seniors. The study was based on convenience sampling. Questionnaire was distributed among the students and identity of the students was not asked thus ensuring confidentiality, but gender, age and educational qualification was documented. Age of the students selected was from 19-21 years. Sample size was small because two private universities were selected. Students in these universities are of high socioeconomic status. For larger sample Public sector universities have to be included and then socioeconomic status differs. Sheesha smoking habits were assessed by asking the following questions:

1. Have you ever been offered sheesha by your friends? $(1=$ Yes, 2 = No)

2. When was the first time you smoked sheesha? $(1=$ School, 2 $=$ College)

3. Do you consider sheesha smoking as fashionable? ( $1=$ Yes, 2 $=$ No)

4. Do you know about the harmful effects of sheesha? $(1=$ Yes, $2=$ No)

5. Are your parents aware about your sheesha smoking habit? (1 $=$ Yes, $2=$ No)

6. Which factor convinced them to smoke? (1= To lose weight, 2 $=$ As a fashionable measure, $3=$ To relieve depression)

7. Should government introduce measures to educate people about the harmful effects of sheesha? $(1=$ Yes, 2 = No $)$

\section{Results}

Analyses were performed by using SPSS version 20 (SPSS Corp., V20, Chicago, IL USA). For each variable, descriptive analyses were applied and percentages were obtained (Table 1). 
Table 1. Percentage of the variables.

\begin{tabular}{l|c|c}
\hline & \multicolumn{2}{|c}{ Percentage } \\
\hline Offer & 51.6 & No \\
\hline First Time Started & 38.5 (school) & 61.1 (college) \\
\hline Fashionable & 68.1 & 30.8 \\
\hline Harmful Effects Known & 44.0 & 54.9 \\
\hline Parents Aware of Habit & 48.4 & 50.5 \\
\hline Gov't Measures to Check & 78.0 & 54.9 \\
\hline Factors & $\begin{array}{l}\text { Lose weight }-35.2 \\
\text { Fashionable - } 41.8 \\
\text { To relieve depression - 22 }\end{array}$ \\
\hline
\end{tabular}

Statistics shows that $51.6 \%$, mean $1.48 \% \pm .502$, of students offer each other the option to smoke sheesha. In this current study's setting, $61.1 \%$ started sheesha smoking during their college life, i.e., mean is $1.61 \% \pm .490$ and is considered fashionable by $68.1 \%$, and $54.9 \%$ were not aware of the harmful effects. Not much difference was seen between the parents about the awareness of their children habit of sheesha smoking i.e., $48.4 \%$ were aware and $50.5 \%$ were unaware. $35.2 \%$ thought of it as losing weight and $22 \%$ to relieve depression (Fig. 1). A large majority (78\%) agreed that government should check this trend of sheesha smoking (Fig. 2).

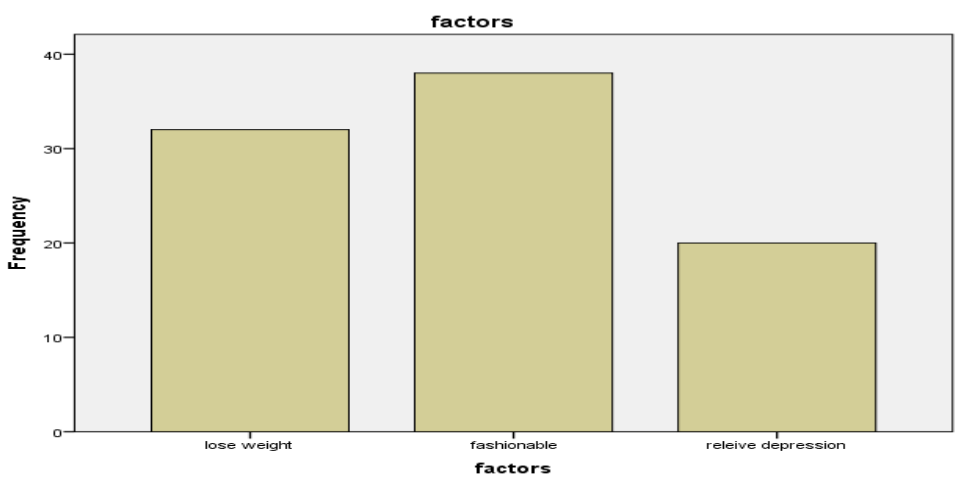

Fig. 1. Frequency of factors responsible for sheesha smoking. 


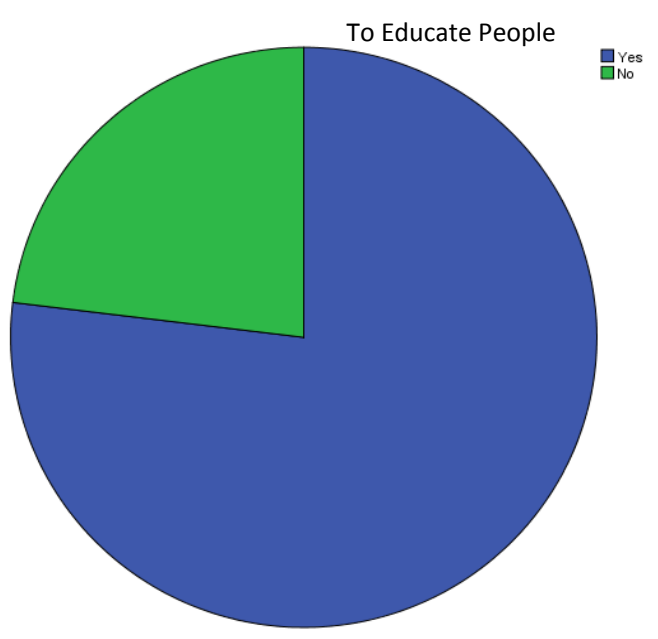

Fig. 2. Education of the people by the government.

\section{Discussion}

Sheesha is a water pipe and its use is becoming popular because of the flavored smoke that is created by heating tobacco, fruit and molasses. It poses a very serious risk to the health of the teenagers, especially females in whom in addition to systemic diseases, the risk of infertility increases along with the fetal abnormalities. According to Manoli et al. maternal smoking is a risk factor for pediatric lung disease, including asthma ${ }^{[8]}$. Sheesha bars are mushrooming in different cities of Pakistan. These bars are crowded with the young adults, majority being college students. One of the study conducted in a hookah (sheesha) bar results showed three factors responsible for this habit which are social facilitation, family/cultural influence, and alternative to smoking cigarettes and drinking ${ }^{[9]}$.

Young Pakistani girls are indulging more into this habit and according to a survey the percentage of female students involved in smoking is 16 percent, which was only 6 percent a few years back ${ }^{[10]}$. Our study shows it is mainly because of two factors; finding it fashionable and secondly to lose weight. Smoking is accepted as cool and stress relieving ${ }^{[11]}$. Weight loss factor is in accordance with the studies conducted by Fulkerson and Austin ${ }^{[12,13]}$, which states that this 
is more common in girls. For both, these aspects media's role is very important, because it shows positive images related to smoking. Fashion shows are increasingly being shown on the TV and the models are seen wearing size zero dresses. This encourages more neutral attitude towards smoking. Strict media legislation control should be enforced to counter such images, to prevent the detrimental effects which it is causing on the young generation. In the present study, about $55 \%$ of the females were not aware of the harmful effects of sheesha smoking and they thought it is different from cigarette smoking because the toxins are neutralized by the water in the sheesha. The same observation was conveyed to Dr. Primack by the students of University of Pittsburgh. He also noted that 92\% of videos on YouTube showed hookah in positive light, compared to just $24 \%$ of cigarette videos ${ }^{[9]}$. As far the knowledge of parents was concerned regarding this habit of their daughters, there was not much difference between the two sets of parents. This study was basically conducted in the colleges and universities where mostly affluent families can afford the studies of their children. In such families checks on the children are not considered important and they consider their daughters grown up and responsible, also there are no financial constraints. Majority of the students were in agreement that the government should take prompt measures to educate the masses more efficiently. To make the anti-sheesha drive more effective government officials should keep a check on the sheesha bars and evaluate them for the banned substances, and media drive should be intensified to highlight the harmful effects of the sheesha smoking. Limitation of the study was that the sample included was small in the sense that only private university female students were included. Secondly, this study can be extended by including boys of the same age group along with both the genders belonging to different socioeconomic status.

\section{Conclusion}

It seems that in our country, the trends of sheesha smoking are increasing in young females mostly because of looking cool, to lose weight and being unaware of its harmful effects. To make the anti- 
sheesha drive more effective, government officials should keep a check on the sheesha bars and evaluate them for the banned substances, and media drive should be intensified to highlight the harmful effects of the sheesha smoking.

\section{References}

[1] Jha P, Ramasundarahettige C, Landsman V, Rostron B, Thun M, Anderson RN, McAfee T, Peto R. 21st-century hazards of smoking and benefits of cessation in the United States. N Engl J Med 2013; 368(4): 341-350

[2] Anjum Q, Ahmed F, Ashfaq T. Shisha smoking: an imminent health hazard. J Pak Med Assoc 2007; 57(9): 430-431.

[3] Harris KJ, Golbeck AL, Cronk NJ, Catley D, Conway K, William KB. Timeline follow-back versus global self-reports of tobacco smoking: a comparison of findings with nondaily smokers. Psychol Addict Behav 2009; 23(2): 368-372.

[4] Hoffmann D, Hoffmann I, El-Bayoumy K. The less harmful cigarette: a controversial issue. A tribute to Ernst L. Wynder. Chem Res Toxicol 2001; 14(7): 767790.

[5] Rezaeetalab F, Rezaeitalab F, Soltaneefa A, Ghaznavi M, Bakhshandeh T, Saberi S. The effect of smoking by family members and friends on the incidence of smoking among high school students. Pneumologia 2012; 61(4): 234-236.

[6] Lewis-Esquerre JM, Colby SM, Tevyaw TO, Eaton CA, Kahler CW, Monti PM. Validation of the timeline follow-back in the assessment of adolescent smoking. Drug Alcohol Depend 2005; 79(1): 33-43.

[7] Patterson F, Lerman C, Kaufmann VG, Neuner GA, Audrain-McGovern J. Cigarette smoking practices among American college students: review and future directions. J Am Coll Health 2004; 52(5): 203-210.

[8] Manoli SE, Smith LA, Vyhlidal CA, An CH, Porrata Y, Cardoso WV, Baron RM, Haley KJ. Maternal smoking and the retinoid pathway in the developing lung. Respir Res 2012; 13(1): 42.

[9] Sharma E, Beck KH, Clark PI. Social context of smoking hookah among college students: scale development and validation. J Am Coll Health 2013; 61(4): 204-211.

[10] Zaman M, Irfan U, Irshad E. Prevalence of cigarette smoking among Peshawar University students. Pak J Chest Med 2002; 8: 9-18.

[11] Watson N, Clarkson JP, Donovan RJ, Giles-Corti B. Filthy or fashionable? Young people's perceptions of smoking in the media. Health Educ Res 2003; 18(5): 554-567.

[12] Fulkerson JA, French SA. Cigarette smoking for weight loss or control among adolescents: gender and racial/ethnic differences. J Adolesc Health 2003; 32(4): 306313.

[13] Austin SB, Gortmaker SL. Dieting and smoking initiation in early adolescent girls and boys: a prospective study. Am J Public Health 2001; 91(3): 446-450. 


\section{عادة تدخين الثيشة في الطالبات الباكستانيات}

\section{أمينة طارق رحيم، وخديجة إقبال، وتمينا شهيد قر'}

قسم الكيمياء الحيوية، معهد راوال للعلوم الصحية، جامعة البحرية، إسلام أباد، قسم التشريح، كلية النفيس الطبية، إسلام أباد 'قسم الكيمياء الحيوية، كلية روالبندي الطبية

$$
\text { روالبندي - باكستان }
$$

الستخلص. وجد أن عادة تدخين الثيشة الأكثر انتشاراً في الفئة

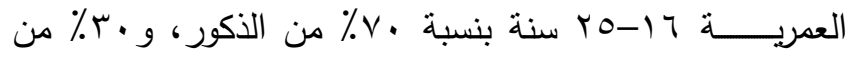

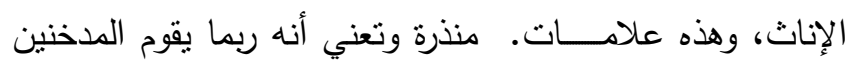

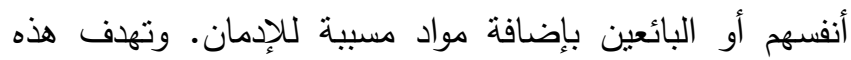

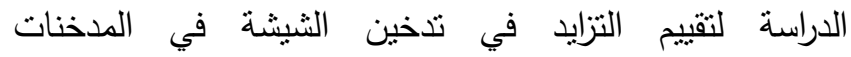

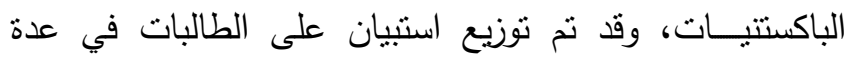

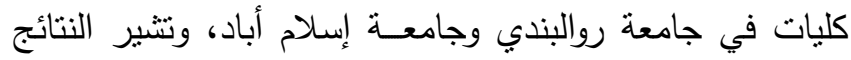

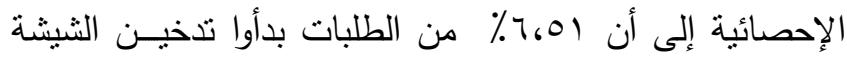

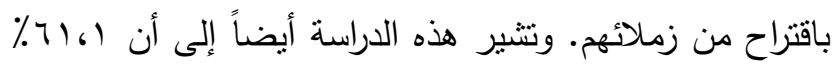

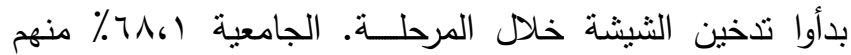

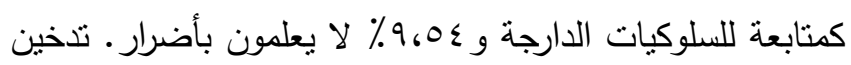
الثيشة كما اتضح أنه لا يوجد فرق بين معرفة أولياء الأمور

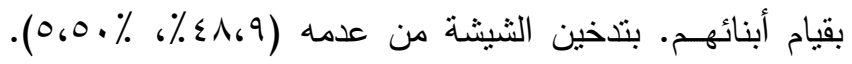

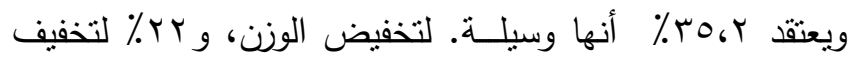

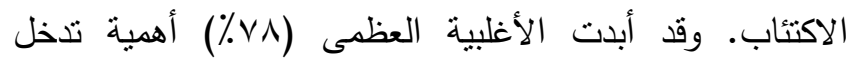

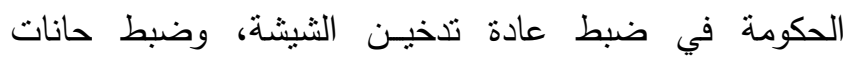

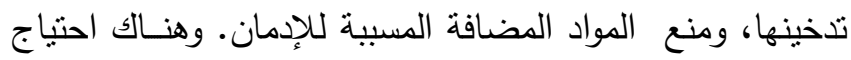
لتوسيع الدراسة لتتمل المدن الصغرى. 